from gradual) evolution has been raised but not resolved (and cannot be as yet). The status of the theory of evolution metaphysical or otherwise? - is still disputed, but the museum is probably too agnostic on these questions.

The museum in its public role deserves some sympathy. Nobody should underestimate the difficulties of a public institution in mounting a defence against such a variety of charges. The most obvious difficulty is that the scientific members of this important institution differ among themselves both on the weight they give to this or that aspect of evolutionary theory and also in their opinions of the public exhibition policy. There are now suggestions that some of the criticisms that have been raised in correspondence and by Nature are concealed attacks on individual members of the museum (and Sir Andrew used the phrase "centering around the scientific thinking of members of the museum's staff"'). This is not the case. The most controversial member of the staff, the head of the Public Services Division which is responsible for the exhibition policy, is acknowledged to have a flair for work of this kind, and would presumably plough some other furrow with equal skill if the trustees chose to change course. The trustees' problem is to devise a unified policy in circumstances in which the staff of the museum, distinguished as independent scientists, cannot be expected to toe some welldefined line. The museum should soon pay some attention to the problem (which afflicts all public laboratories) of how to marry the need for some coherent outward face with the inevitable diversity of opinion among its staff. The museum, which courageously has not been afraid to amend the most (and needlessly) tactless part of its newest exhibition, might think of helping other public institutions to a seemly solution of this increasingly common problem.

\section{Public but going private}

Is the British government about to be still more beastly to the nationalized industries it has reluctantly inherited? There are several signs that this may be the case. Last week, the government decreed that the British Gas Corporation (which has for a year been resisting the proposal that it should cease to be a major retailer of domestic gas-burning equipment) should sell its halfshare in a small onshore oil field in Dorset, evoking the predictable chorus of anguish from the corporation, which is plainly unsure whether it is a public utility or a kind of conglomerate. A more important development has, however, gone comparatively unnoticed. For now, it seems, the British government is bent on making public agencies in the United Kingdom abandon their long-standing belief that their own definition of their own needs should properly take precedence over the needs of their customers in the marketplace. The document put out by the Department of Industry in mid-June, formally a reply to the perceptive report Research and Development for Public Purchasing put out by the Advisory Council for Applied Research and Development more than a year earlier, promises - or threatens - substantial changes in the pattern of British research and development.

The problem is uniquely British. The original report estimated that at least 40 per cent, and perhaps a half, of all applied research and development carried out in the United Kingdom is (or was, in 1975) determined by the needs of British public agencies. The public agencies (government departments, nationalized industries and the research councils) are also eager researchers in their own right; public in-house research and development was running at roughly a third of all British research and development in 1975. A rather greater proportion of defence research and development (some 60 per cent) is put out to private industry on a contract basis than in other fields of the public interest, but this appearance of virtue may be illusory in that the chief beneficiary is the aerospace industry.

The Advisory Council's perceptive complaint, in February 1980 , was not that the sums of money involved were too large (which is a different argument) but that government departments and nationalized industries have wrongly chosen the line of demarcation between themselves and private industry. For, in the most general sense, the objective of most public spending on applied research and development is to define the specification of some product - an aircraft or a repeater in a submarine telephone cable - whose manufacture will afterwards be put out to tender. Manufacturers are always willing enough to put in their bids. Who, after all, wants to turn down business, especially from a customer that can always print the money to pay for what it buys if it cannot otherwise get the funds? The snag, and the chief conclusion of the Advisory Council's report, is that in the cosy relationship that grows up between a paternalistic public sector, willing to shoulder all the cost of research and development itself, and would-be suppliers, scant regard is paid to the long-term interests of the public contractors. Too little of what they make for British government agencies will sell easily elsewhere. Too little of what they spend on research and development goes on the improvement of products that will sell in the wider marketplace.

The Advisory Council's analysis is by no means new. In the 1960 s, after a long period of an over-cosy and restrictive relationship with the British Post Office, even the suppliers of telecommunications equipment came to appreciate that the benefits were illusory (yet not a lot has changed since then). The novelty of last year's report was that it advocated a few simple rules of thumb for distributing the balance of research and development between public customers and private contractors. Government and other public agencies have a proper right, even a duty, to carry out research suggesting ways in which the character of their operations may be improved or ways of improving or monitoring the conduct of their existing operations, in matters such as safety. On the other hand, if goods and services are likely primarily to sell to other public customers, the supplier should carry out the necessary research, perhaps with some public help. In intermediate cases, public and private responsibility for research and development should be shared. In general, more publicly supported research and development should be contracted out to private industry.

Rarely can a government's reply to the report of an advisory committee have been as fulsome. With a few justifiable quibbles (where the government is anxious to avoid robbing nationalized industries of their formal autonomy), all the principal recommendations are enthusiastically endorsed. Three government departments (including that for defence, the biggest spender) are said already to have decided to put out more of their research and development. Now the nationalized industries are to be asked to follow suit, but also to find ways in which their own research establishments can sell services overseas. So is a new day dawning for applied research and development in Britain?

The government's enthusiasm is accounted for by its ideology. For months (it seems like years) the government has been talking about "privatization". The Advisory Council's arguments are more objective and thus more persuasive. But everything depends on how effectively the new prescription is carried out. Here doubt persists. The government is probably right not to follow the Advisory Council in the suggestion that there should be an independent board to supervise the fashioning of a new relationship between the public and private sectors in every nationalized industry, but the result will be that final decisions will be made within government departments all too comfortable with past relationships. Conscious as many of the departments will be of the difficulties of managing a substantial shift of resources (for their own laboratories for example) the departments will draw the new lines of demarcation cautiously. This is the respect in which both the original recommendations and the British government's response are inadequate. If the balance of research and development between the public and private sectors is to be shifted substantially, there needs to be some way of anticipating the problems that will arise (such as those afflicting the 75,000 or so people on the government's own research payroll). And there needs also to be, for this purpose and others, some means of letting ministers and taxpayers know what is happening, or about to happen. 